Hikmah: Journal of Islamic Studies, 16 (1), 2020, 57-82

http://journal.uinjkt.ac.id/index.php/HIKMAH

DOI: 10.47466/hikmah.v16i1.167 | P-ISSN. 2088-2629, E-ISSN. 2581-0146

\title{
PERANAN PERHATIAN ORANG TUA DALAM MENSTIMULUS KECERDASAN KOGNISI ANAK
}

\author{
Nofi Maria Krisnawati \\ Sekolah Tinggi Agama Islam Al-Hikmah Jakarta, Indonesia \\ nofimaria.73@gmail.com
}

\begin{abstract}
The research on the role of parents in stimulating children cognitive intelligence aims to uncover parents attention to the children cognitive intelligence, namely the result of learning. It is a nonexperiment qualitative research examined to 33 students the fourth grade in social sciences subject. The date is qualitatively and descriptively analysed. The result shows that parents attention influences the stimulus of children cognitive intelligence. It can be concluded from the result of student learning. The result is in line with calculated-t hypothesis greater than ttabel with $\mathrm{dk}=\mathrm{n}-\mathrm{k}$ $=33-2=31$ on significant level 0,05 . A one-tailed test is 1.695 meaning t value $(17,447)$ is greater than ttabel $(1,695)$. It means Ho rejected. Therefore, the hypothesis is sound that parents attention contributes positively to the stimulus of children cognitive intelligence. It can be seen form the student result of learning. In other word, the more attention the parent give to the children, the better the result of children's learning and vice versa.
\end{abstract}

Keywords: Parental attention; Stimulus; Cognitive Intelligence

\begin{abstract}
Abstrak
Penelitian peranan perhatian orang tua dalam menstimulus kecerdasan kognisi anak bertujuan untuk mengetahui pengaruh perhatian orang tua terhadap kecerdasan kognisi anak yang berupa hasil belajar. Penelitian ini merupakan penelitian kuantitatif non experiment yang diujicobakan kepada 33 peserta didik kelas IV mata pelajaran IPS, sedangkan data dianalisis secara diskriptif kualitatif. Hasil penelitian menunjukkan perhatian orang tua mempengaruhi stimulus kecerdasan kognisi anak, dapat dilihat dari hasil belajar siswa IPS. Hal ini sesuai dengan pengujian hipotesis $t$ hitung yang lebih besar dari $t_{\text {tabcl }}$ dengan $d k=n-k=33-2=31$ pada taraf signifikansi 0,05 uji satu sisi adalah 1.695 yang berarti $t_{\text {hitung }}(17,447)$ lebih besar dari $t_{\text {tabel }}(1,695)$ hal ini berarti $H_{o}$ ditolak. Dengan demikian hipotesis penelitian terbukti kebenarannya bahwa Perhatian Orang Tua berpengaruh positif terhadap stimulus kecerdasan kognisi anak yang berupa hasil belajar siswa. Simpulannya bahwa adanya pengaruh perhatian orang tua dalam menstimulus kecerdasan kognisi anak, yang mana semakin tinggi perhatian orang tua, maka cenderung semakin tampak kecerdasan anak dari segi hasil belajarnya, sebaliknya semakin rendah perhatian orang tua maka semakin rendah pula hasil belajarnya.
\end{abstract}

Kata Kunci: Perhatian orang tua; Stimulus; Kecerdasan Kognisi 


\section{PENDAHULUAN}

Pendidikan merupakan upaya pemerintahan untuk meningkatkan kualitas sumber daya manusia, selain itu pendidikan juga menjadi tuntutan terhadap hak warga Negara. ${ }^{1}$ Hak dari setiap warga negara Indonesia tidak hanya sekedar memperoleh pelayanan pendidikan yang semakin baik. Oleh karenanya pemerintah menyelenggarakan suatu sistem pendidikan nasional yang tertuang dalam UU Nomor 20 Tahun 2003. ${ }^{2}$ Berdasarkan undang-undang tersebut, maka dari waktu ke waktu bidang pendidikan haruslah tetap menjadi prioritas dan menjadi orientasi untuk ditingkatkan dan dikembangkan agar tujuan pendidikan nasional dapat terwujud. Demi mewujudkan tujuan pendidikan nasional, pemerintah, keluarga dan masyarakat mempunyai tanggung jawab yang sama. Dari lingkungan belajar tersebut yang paling pertama dikenal anak adalah pendidikan yang berlangsung dalam keluarga yang diberikan oleh orang tuanya di mana anak lahir dan dibesarkan. Hal ini sejalan dengan pendapat Nana Syaodih Sukmadinata, keluarga sering disebut sebagai lingkungan pertama, sebab dalam lingkungan inilah pertama-tama anak mendapatkan pendidikan, bimbingan, asuhan, pembiasaan, dan latihan. ${ }^{3}$ Keluarga bukan hanya menjadi tempat anak dipelihara dan dibesarkan, tetapi juga tempat anak hidup dan dididik pertama kali.

Keluarga mempunyai peranan dan tanggung jawab utama atas perawatan dan perlindungan anak sejak bayi hingga remaja. ${ }^{4}$ Pengenalan anak kepada kebudayaan, pendidikan, nilai dan norma-norma kehidupan bermasyarakat dimulai dalam lingkungan keluarga perkembangan kepribadian anak-anak yang sempurna dan serasi, mereka harus tumbuh dalam lingkungan keluarga dalam suatu iklim kebahagiaan, penuh kasih sayang dan pengertian. ${ }^{5}$ Pada hakekatnya, setiap orang tua mempunyai harapan agar anak-anaknya tumbuh dan berkembang menjadi anak yang baik dan soleh, agar tidak terjerumus kepada perbutan-perbuatan yang dapat merugikan dirinya sendiri manupun orang lain. Harapanharapan ini kiranya lebih mudah terwujud apabila sejak semula orang tua menyadari akan peranan mereka sebagai orang tua harus memperhatikan anak setiap hari walaupun sesibuk apapun, anak jangan sampai terlupakan dalam mengontrol dan mendidiknya, memberi kasih sayang dan memberi bimbingan.

Kriteria tingkat perhatian yang dimaksud dalam penelitian ini didasarkan pada perhatian ditinjau dari derajatnya yang meliputi perhatian tinggi dan rendah. Menurut para ahli, perhatian dari keluarga/orang tua sebagai lingkungan utama, pertama dan yang paling

\footnotetext{
${ }^{1}$ Tim Pengembang Ilmu Pendidikan FIP-UPI, Ilmu dan Aplikasi Pendidikan, (Bandung: PT. Iperial Bhakti Utama, 2007), h. 32

${ }^{2}$ Tim Pengembang Ilmu Pendidikan FIP-UPI, Ilmu dan Aplikasi Pendidikan, h. 32.

${ }^{3}$ Nana Syaodih Sukmadinata, Landasan Psikologi Proses Pendidikan, (Bandung: PT Remaja Rosdakarya, 2004), h. 6

${ }^{4}$ Feisal Jusuf Amir, Reorientasi Pendidikan Islam, (Jakarta: Gema Insani Press, 1995), h. 37

${ }^{5}$ Komisi Perlindungan Anak, Undang-undang Perlindungan Anak, (Jakarta: New Merah Putih, 2004), h. 85
} 
dekat dengan anak menjadi hal terpenting. Pengertian, penerimaan, pemahaman, serta bantuan orang tua menjadi sangat berarti bagi anak guna mengarahkan kehidupan dan pencapaian prestasi belajarnya. Sebagaimana yang disampaikan Tabrani Rusyan dkk, bahwa perhatian orang tua dalam belajar anaknya merupakan faktor penting dalam membina sukses belajar. Kurangnya perhatian orang tua dapat menyebabkan anak malas, acuh tak acuh, dan kurang minat belajar. ${ }^{6}$ Di sepanjang tahun, khususnya pada tahun ajaran baru, prestasi belajar yang berkaitan dengan pencapaian tujuan pendidikan secara umum di segala jenjang pendidikan formal, termasuk pada madrasah ibtidaiyah (MI) sering dipermasalahkan.

Perhatian orang tua secara simultan juga dapat membantu dan mendorong anak-anak untuk dapat lebih berhasil dalam pendidikannya, peran orang tua dalam pendidikan anak adalah memberikan bantuan, dukungan/motivasi dan informasi tentang cara belajar yang baik dan tepat. ${ }^{7}$ Dua hal tersebut di atas menunjukkan bahwa dengan adanya peranan orang tua dapat menstimulus kecerdasan anak yang pada akhirnya akan menimbulkan rasa percaya diri pada diri si anak yang pada akhirnya sikap ini akan memunculkan kemandirian belajar pada dirinya pula. Perhatian orang tua dapat menumbuhkan sifat dan sikap positif merujuk pada mengetahui tentang keunggulan maupun kelemahan itu. Berbagai ciri orang yang memiliki sifat seperti tersebut cenderung bangga terhadap kemampuan dirinya sendiri, selalu memperjuangkan kemampuannya secara penuh, pantang mundur, menerima dirinya sendiri maupun orang lain apa adanya, dan tidak lari dari kenyataan.

Siska Eko Mawarsih, Susilaningsih, Nurhasan Hamidi dalam jurnalnya menyampaikan bahwa, perhatian yang tepat dan benar diberikan orang tua kepada anaknya dalam kegiatan belajar akan meningkatkan semangat belajar anak untuk meraih prestasi yang tinggi. ${ }^{8}$ Peranan orang tua sangat penting misalnya pada saat guru memberikan pekerjaan rumah, diperlukan bimbingan orang tua dalam memecahkan masalah yang dihadapi anak. Peranan orang tua sangat tinggi dalam menentukan prestasi siswa, dalam hal ini orang tua memperhatikan pendidikan anaknya tentu akan selalu memperhatikan kebutuhan belajar anaknya. Perhatian tersebut dapat berbentuk penyediaan fasilitas belajar yang cukup, bimbingan belajar di rumah baik yang dilakukan secara langsung ataupun tidak langsung. Pada tataran mikro dapat kita lihat bahwa siswa yang mempunyai orang tua yang memberikan perhatian tinggi terhadap kebutuhan untuk pendidikan anaknya, kuat kemungkinannya untuk dapat mencapai prestasi yang lebih baik. ${ }^{9}$

\footnotetext{
${ }^{6}$ Tabrani Rusyan dkk, Pendekatan dalam Proses Belajar-Mengajar, (Bandung: PT Remaja Rosdakarya, 1994), h. 196

${ }^{7}$ Agus Suprijono, Cooperative learning: teori \& aplikasi PAIKEM, (Jakarta: Pustaka Pelajar, 2013), h. 23

${ }^{8}$ Siska Eko Mawarsih, Susilaningsih, Nurhasan Hamidi, Pengaruh Perhatian Orang Tua dan Motivasi Belajar terhadap Presatsi Belajar Siswa SMA Negeri Jumapolo, Juni 2013, Pendidikan Ekonomi-BKK Akuntansi, FKIP Universitas Sebelas Maret, Surakarta, JUPE UNS, Vol. 1, No. 3

${ }^{9}$ Slameto, Belajar dan Faktor-faktor yang Mempengaruhinya, (Jakarta: Rineka Cipta, 2003), h. 32
} 
Pada penilitian yang dilakukan Eka Prasetya disebutkan, hasil penelitian menunjukkan bahwa ada hubungan positif sangat signifikan antara hubungan perhatian orang tua dengan hasil belajar matematika, hal ini tampak pada $r=0,717$, dengan taraf signifikansi 0,00 . Sumbangan perhatian orang tua terhadap hasil belajar siswa sebesar $51,4 \%$ dan $48,6 \%$ merupakan faktor-faktor lain yang mempengaruhinya. ${ }^{10}$

Kelas 4 MI merupakan titik tengah keberadaan anak di sekolah dasar, masa transisi dari ketergantungan menuju ke kemandirian anak. Peserta didik pada kelas ini sudah dapat berpikir sendiri dan mulai memiliki pola terhadap kebiasaan belajarnya. Salah satu pelajaran yang sering menemukan kendala adalah pelajaran Ilmu Pengetahuan Sosial (IPS) karena pelajaran ini menuntut banyak hapalan sehingga dianggap susah. Standar kompetensi pelajaran IPS Kelas 4 adalah memahami sejarah, kenampakan alam, dan keragaman suku bangsa di lingkungan kabupaten/ kota dan provinsi dengan kompetensi dasar menunjukkan jenis dan persebaran sumber daya alam serta pemanfaatannya untuk kegiatan ekonomi di lingkungan setempat.

Pada kenyataannya selama ini materi jenis dan persebaran sumber daya alam serta pemanfaatannya untuk kegiatan ekonomi di lingkungan setempat pada MI Al Makmur Ciganjur masih banyak siswa yang memperoleh nilai di bawah Kriteria Ketuntasan Minimal (KKM). KKM yang ditetapkan oleh madrasah adalah 68 untuk pelajaran IPS. Faktor-faktor yang mempengaruhi prestasi belajar siswa tentunya beraneka ragam, tetapi secara garis besar ada dua faktor yaitu Intern (dalam diri siswa) dan Ekstern (dari luar siswa). Dalam pembelajaran IPS siswa cenderung acuh, malas dan kurang berminat dengan materi yang diajarkan, sehingga guru perlu bekerja sama dengan orangtua untuk dapat meningkatkan hasil belajar IPS siswa melalui perhatian yang lebih. Perhatian orang tua kepada siswa terhadap pelajaran IPS diduga mempengaruhi prestasi belajar siswa.

Rendahnya tingkat kecerdasan kognisi anak yang dilihat dari hasil belajar yang dicapai oleh sebagian siswa dipengaruhi oleh beberapa faktor baik faktor internal maupun eksternal. Faktor internal antara lain: perhatian orang tua, motivasi, minat, kebiasaan, kemandirian belajar dan lain-lain. Sedangkan faktor eksternal antara lain sarana dan prasarana, guru, orang tua dan lain-lain. Berdasar pre-research yang penulis lakukan terhadap siswa Kelas IV MI Al Makmur Ciganjur Jakarta Selatan. Hasil observasi menunjukkan ada siswa yang prestasi IPSnya bagus ternyata perhatian orang tuanya tinggi. ${ }^{11}$ Sebaliknya, ada siswa yang prestasi IPSnya kurang atau sedang ternyata setelah

\footnotetext{
${ }^{10}$ Eka Prasetya, Hubungan Perhatian Orang Tua Dengan Hasil Belajar Siswa Kelas IV Pada Mata Pelajaran Matematika SD Negeri Serang Kecamatan Pengasih Kabupaten Kulon Progo, Program Studi Pendidikan Guru Sekolah Dasar Jurusan Pendidikan Pra Sekolah Dan Sekolah Dasar Fakultas Ilmu Pendidikan Universitas Negeri Yogyakarta, Juni 2012

${ }^{11}$ Observasi penulis terhadap Ad dan Bp/Ibu S (orang tua) tanggal 25 s.d. 27 September 2019; terlihat orang tua kurang memperdulikan acara tv yang ditonton anak, jarang menanyakan ketika anak pulang terlambat atau lebih awal
} 
penulis telusuri ternyata perhatian orang tuanya minim. ${ }^{12}$ Adanya fakta tersebut, penulis tertarik untuk mengetahui dan meneliti lebih lanjut kaitan antara peranan perhatian orang tua dalam menstimulus tingkat kecerdasan kognisi anak dalam bidang studi Ilmu Pengetahuan Sosial (IPS) dengan judul "Peranan Perhatian Orang Tua dalam Menstimulus Kecerdasan Kognisi Anak".

\section{METODE}

Metode penelitian yang akan digunakan dalam penelitian ini adalah metode kuantitatif non eksperimen dengan menggunakan data yang berupa angka. Penelitian ini dilakukan peneliti dengan menggunakan angket untuk mengetahui peranan perhatian orang tua sebagai variabel bebas (independent variable) dalam menstimulus kecerdasan kognisi anak yang berupa hasil belajar (dependent variable).

\section{Populasi dan Sampel}

Populasi dalam penelitian ini adalah siswa sekolah dasar di wilayah kelurahan Cipedak. Menurut Sugiyono, sampel adalah bagian dari jumlah dan karakteristik yang dimiliki oleh populasi tersebut. ${ }^{13}$ Penelitian sampel baru boleh dilaksanakan apabila keadaan subjektif di dalam populasi benar-benar Homogen. Sampel Penelitian ini dilakukan dengan menggunakan teknik cluster random sampling, karena didalam pengambilannya terdiri dari dari dua tahapan. Sampel yang dilakukan secara acak dengan menggunakan pengundian. Tahap pertama peneliti menentukan daerah yang akan dijadikan sampel secara random, pengundian tersebut yaitu kelurahan Cipedak. Kemudian tahap kedua menentukan peserta didik yang akan dijadikan sampel secara random. Sampel pada penelitian ini adalah 33 peserta didik mata pelajaran IPS Kelas IV di MI Al Makmur Cipedak.

\section{Teknik Pengumpulan Data}

Data merupakan suatu bahan yang sangat diperlukan untuk diteliti/dianalisis, maka dari itu diperlukan suatu teknik pengumpulan data yang sesuai dengan tujuan penelitian. Teknik pengumpulan data yang digunakan dalam penelitian ini adalah dokumentasi dan angket. Dokumentasi digunakan untuk mengambil hasil belajar pelajaran IPS yang ada

\footnotetext{
dari biasanya, memanjakan anak dengan jarang menyuruhnya membantu mengerjakan pekerjaan rumah dan ternyata nilai IPSnya 74 (cukup).

${ }^{12}$ Observasi penulis terhadap Ra dan Bp/Ibu Na (orang tua) tanggal 25 s.d.27 September 2019; terlihat orang tua selalu menanyakan ketika anak pulang terlambat atau lebih awal dari biasanya, selalu menyuruh membantu mengerjakan pekerjaan rumah, menasihati anak dengan bahasa yang santun ketika anak bertindak kurang sopan dan ternyata nilainya 76 (sedang). Observasi penulis terhadap Do dan Bp/Ibu Re terlihat orang tua membatasi jam dan acara tv yang ditonton anak, selalu menanyakan ketika anak pulang terlambat atau lebih awal dari biasanya, selalu menyuruh membantu mengerjakan pekerjaan rumah dan ternyata nilai IPSnya 80 (tinggi).

${ }^{13}$ Ibid., h. 118 .
} 
pada guru kelas dan angket digunakan untuk mengetahui perhatian orang tua pada siswa. Adapun tahapan-tahapan yang dilakukan dalam pengumpulan data pada penelitiaan ini adalah sebagai berikut :

1. Tahap Persiapan

a. Permohonan ijin penelitian kepada sekolah MI Al Makmur Ciganjur

b. Permohonan ijin kepada guru kelas IV sekaligus menanyakan secara singkat keadaan siswa kelas IV secara global

c. Menyiapkan instrumen penelitian yaitu angket tentang perhatian orang tua

2. Tahap Pelaksanaan

a. Masuk kelas IV waktu jadwal pelajaran IPS

b. Berkenalan dan tanya jawab tentang pelajaran IPS kepada siswa

c. Menyampaikan kepada siswa tentang maksud kehadiran peneliti

d. Membagikan angket kepada siswa dengan penjelasan tentang isi angket dan cara menjawab angket

3. Tahap akhir

a. Mengumpulkan data yang diperoleh.

b. Mengolah data hasil penelitian.

c. Menganalisis dan membahas hasil temuan penelitian.

d. Menarik kesimpulan.

\section{Instrumen Penelitian}

Instrumen penelitian yang digunakan sebagai alat pengumpul data dalam penelitian ini adalah sebagai berikut:

1. Angket Perhatian Orang Tua $\left(\mathrm{X}_{1}\right)$

Angket untuk mengukur perhatian orang tua dibuat dalam bentuk rating sejauh mana indikator-indikator perhatian orang tua dapat menunjang pembelajaran. Pilihan jawaban adalah Selalu (SL), Sering (SR), pernah (P), Jarang (JR) dan Tidak Pernah (TP). Penskoran untuk butir positif adalah $\mathrm{SL}=5, \mathrm{SR}=4, \mathrm{P}=3, \mathrm{JR}=2$ dan $\mathrm{TP}=1$. Skor akhir ialah penjumlahan seluruh skor butir. Selanjutnya nilai yang diperoleh dibandingkan 
dengan kriteria untuk ditarik kesimpulan. Nilai terendah diperoleh sebesar 24 skor, dan skor tertinggi adalah 120 . Sehingga diperoleh tabel kelas interval sebagai berikut:

Tabel 3.2.

Kelas interval

\begin{tabular}{|ll|l|}
\hline \multicolumn{2}{|l|}{ Interval } & Kriteria \\
\hline $1-24$ & Sangat Rendah \\
\hline $25-48$ & Rendah \\
\hline $49-72$ & Sedang \\
\hline $73-96$ & Tinggi \\
\hline $97-120$ & Sangat Tinggi \\
\hline
\end{tabular}

Sumber: Data primer diolah

Tabel di atas diperoleh dengan menggunakan langkah sebagai berikut :

Kriteria $=$ poin $\mathrm{x}$ jumlah pernyataan

a. Kriteria Maksimal Sangat Rendah $=1 \times 24=24$

b. Kriteria Maksimal Rendah $=2 \times 24=48$

c. Kriteria Maksimal Sedang $=3 \times 24=72$

d. Kriteria Maksimal Tinggi $=4 \times 24=96$

e. Kriteria Maksimal Sangat Tinggi $=5 \times 24=120$

Penjelasan untuk rumus di atas dapat dijabarkan sebagai berikut: Skor terendah berarti perhatian orang tua sangat rendah ketika diperoleh total skor sebanyak 24 yang berarti dari keseluruhan butir anak menjawab tidak pernah, skor rendah diperoleh pada total maksimal skor 48 dimana kemungkinan siswa menjawab jarang pada keseluruhan butir. Skor cukup baik perhatian orang tua apabila maksimal skor diperoleh adalah 72 yang kemungkinan jawaban keseluruhan adalah Pernah. Perhatian orang tua berada pada kategori baik adalah ketika skor perhatian orang tua maksimal diperoleh siswa sebesar 96 dan perhatian orang tua adalah sangat baik apabila skor maksimal diperoleh pada angket perhatian orang tua adalah sebanyak 120 . Hal ini berarti perhatian orang tua yang baik pada batas minimal 96 dan batas maksimal adalah 120 .

\section{Kalibrasi Instrumen}

Instrumen penelitian yang digunakan adalah menggunakan tes pilihan ganda (multiple choise test). Sebelum instrumen digunakan untuk mengukur kecerdasan kognisi anak dari hasil belajar siswa maka terlebih dahulu diadakan uji coba untuk mengetahui tingkat validitas, dan reliabilitas.

\section{Uji Validitas Instrumen}


Validitas Instrumen adalah tingkat keabsaan suatu tes. Dikatakan valid apabila instrumen dapat mengukur secara tepat sesuatu yang akan diukur. Dalam proses pengukuran responden harus merasa bebas tanpa beban. Pengujian validitas dilakukan dengan rumus teknik korelasi "product moment" sebagai berikut:

$$
r=\frac{n \sum \chi-\sum \chi \cdot \sum \gamma}{\sqrt{n\left(\sum \chi^{2}\right)-\left(\sum \chi\right)^{2} \cdot \sqrt{n\left(\sum \gamma^{2}\right)-\left(\sum \gamma\right)^{2}}}}
$$

Keterangan :

$\mathrm{n}=$ jumlah data

$\mathrm{x}=$ nilai butir soal

$y=$ total nilai

Koefisien korelasi butir $\left(\mathrm{r}_{\text {hitung }}\right.$ ) untuk 24 butir instrumen dengan sampel 33 orang (n $=33$ orang), dengan $\alpha=0.05$ didapat $r_{\text {tabel }} 0,344$, artinya bila $r_{\text {hitung }}<r_{\text {tabel }}$ maka butir instrumen tidak valid dan apabila $r_{\text {hitung }}>r_{\text {tabel }}$, maka butir instrumen tersebut dapat digunakan (valid). ${ }^{14}$ Dari hasil perhitungan statistik untuk masing-masing butir soal, $\mathrm{r}_{\text {hitung }}$ yang diperoleh lebih besar dari $r_{\text {tabel}}$, sehingga dikatakan bahwa semua butir kuesioner berpredikat valid. Perhitungan dalam penelitian ini menggunakan bantuan program komputer untuk statistik yaitu SPSS Versi 23.0.

\section{Uji Reliabilitas Instrumen}

Reliabilitas tes adalah tingkat konsistensi suatu instrumen, yaitu untuk mengukur sejauh mana suatu tes dapat dipercaya untuk menghasilkan skor yang konsisten. Uji reliabilitas dalam penelitian ini menggunakan teknik belah dua. Sesuai dengan Imam bahwa, "Teknik belah dua (tes belah dua) ialah suatu instrumen tes diujicobakan kepada kelompok tertentu kemudian dihitung skornya." ${ }^{\prime 15}$ Dengan menggunakan rumus Cronbach Alpha pada Imam, sebagai berikut : ${ }^{16}$

$\alpha=\left(\frac{k}{k-1}\right)\left(1-\frac{\sum s_{i}^{2}}{s_{t}^{2}}\right)$

Keterangan :

$\alpha \quad=$ Koefisien reliabilitas tes

$k \quad=$ cacah butir

$s_{i}^{2} \quad=$ varian skor butir

\footnotetext{
${ }^{14}$ Ibid.

${ }^{15}$ Imam, Metode Penelitian, (Jakarta: Unindra Press, 2013), h.150

${ }^{16}$ Ibid, h. 152
} 


$$
s_{t}^{2} \quad=\text { varian skor total }
$$

Hasil perhitungan uji reliabilitas maka diperoleh koefisien reliabilitas dengan 24 butir soal diinterpretasikan berdasarkan tabel berikut untuk melihat tingkat reliabelnya.

Tabel 3.4.

$$
\text { Klasifikasi koefisien reliabilitas }{ }^{17}
$$

\begin{tabular}{|l|l|}
\hline $0,80-1,00$ & Sangat tinggi \\
\hline $0,70-0,79$ & Tinggi \\
\hline $0,60-0,69$ & Sedang \\
\hline$<0,60$ & Rendah \\
\hline
\end{tabular}

Perhitungan dalam penelitian ini menggunakan bantuan program komputer untuk statistik yaitu SPSS Versi 23.0 dengan uji reliabilitas Alpha Cronbach's yang berpedoman pada dasar pengambilan keputus yang telah ditentukan pada tabel 3.4. di atas.

\section{Kecerdasan Kognisi}

Ketercapaian kecerdasan kognisi dapat dilihat dari hasil belajar siswa yang dilakukan dengan memberikan tes pada pelajaran IPS yang kemudian dilakukan ujicoba untuk mengetahui masing-masing soal layak untuk dilakukan penelitian. Uji validitas hasil belajar dilakukan dengan menghitung hasil sebaran soal yang telah disebarkan kepada siswa sebagai uji coba instrumen dengan menggunakan bantuan SPSS. Soal untuk hasil belajar terdiri dari 26 soal, yang disebarkan kepada 33 orang responden, diperoleh hasil $\mathrm{r}$ tabel adalah sebesar 0,344 sehingga apabila hasil perhitungan diperoleh $r$ hitung lebih besar dari $r$ tabel maka butir pernyataan dinyatakan valid dan apabila diperoleh $r$ hitung lebih kecil dari $r$ tabel maka item pernyataan dinyatakan tidak valid dan perlu dilakukan perubahan atau dihapus dan tidak digunakan dalam penelitian. Uji reliabilitas instrumen hasil belajar dilakukan dengan bantuan SPSS dengan hasil yang diperoleh adalah cronbach's alpha (koefisien reliabilitas) dibandingkan dengan tabel 3.4. Klasifikasi koefisien reliabilitas, sehingga dapat dilihat apakah angket memiliki reliabilitas yang Sangat tinggi, Tinggi, Sedang, ataupun Rendah. Instrumen final adalah butir-butir instrumen yng dinyatakan valid dan reliabel berdasarkan hasil ujicoba instrumen yang telah dilakukan. Instrumen final tersebut selanjutnya akan digunakan sebagai instrumen penelitian.

\section{Teknik Analisa Data}

Teknik analisis data merupakan prosedur penelitian yang digunakan untuk proses data agar data mempunyai makna untuk menjawab masalah dalam penelitian ini dan menguji hipotesis. Data-data tersebut dianalisis melalui dua tahap sebagai berikut:

\footnotetext{
${ }^{17}$ Suharsimi Arikunto, Prosedur Penelitian, (Jakarta: Rineka Cipta, 2013), h. 75
} 
1. Statistik Deskriptif

Statistik deskriptif dilakukan dengan melakukan perhitungann mean, median, modus, terhadap masing-masing variable yang diteliti. Serta dibuat sebaran data atau distribusi frekuensi untuk melihat seberapa sebaran data yang dimiliki dalam penelitian. Statistik deskriptif dilengkapi dengan grafik histogram untuk dapat memberikan gambaran yang lebih jelas terhadap sebaran data pada masing-masing variabel.

2. Statistik Inferensial

Statistik inferensial dilakukan persyaratan analisis yakni dengan proses pengujian analisis normalitas dan homogenitas.

\section{Uji Normalitas}

Uji normalitas dilakukan untuk mengetahui apakah data yang berhasil dijaring berdistribusi normal atau tidak. Rumus yang digunakan adalah rumus uji normalitas Liliefors dengan taraf signifikasi $\alpha=0,05$. Rumus uji Liliefors adalah sebagai berikut: ${ }^{18}$

$$
\mathrm{L}_{0}=|\mathrm{F}(\mathrm{Zi})-\mathrm{S}(\mathrm{Zi})|
$$

Keterangan:

$\mathrm{L}_{0} \quad$ : Harga mutlak terbesar

$\mathrm{F}(\mathrm{Zi})$ : Peluang angka baku

$\mathrm{S}(\mathrm{Zi}) \quad$ : Proporsisi angka baku

Uji normalitas dalam penelitian ini dilakukan dengan menggunakan bantuan SPSS Versi 23.0 dengan Data yang akan diuji normalitas adalah data pada variabel $\mathrm{X}$, dan $\mathrm{Y}$ dimana data berskala rasio (hal ini memenuhi syarat uji normalitas). Uji normalitas ini bertujuan untuk mengetahui apakah data yang terjaring dari masing-masing variabel berdistribusi normal atau tidak. Uji normalitas ini menggunakan metode Kolmogorov Smirov (uji K-S). Untuk menentukan normalitas dari data yang diuji cukup dengan membaca nilai Asymp. Sig. (2-tailed).

Untuk mengetahui apakah sampel berasal dari populasi yang berdistribusi normal, nilai $\mathrm{L}_{0}\left(\mathrm{~L}_{\text {hitung }}\right)$ dibandingkan dengan nilai kritis $\mathrm{Lt}\left(\mathrm{L}_{\text {tabec }}\right)$ pada taraf signifikasi $\alpha=0,05$ kriteria pengujian populasi ini dianggap berdistribusi normal jika nilai $\mathrm{L}_{0}\left(\mathrm{~L}_{\text {hitung }}\right)$ lebih kecil dari $\mathrm{L}_{\mathrm{t}}\left(\mathrm{L}_{\text {tabe }}\right)$.

\section{Uji Homogenitas}

Uji homogenitas digunakan untuk mengetahui apakah kedua kelompok sampel berasal dari populasi yang sama atau tidak sama. Dengan menggunakan Test of Homogenity of Variance. Langkah-langkah uji homogenitas pada SPSS Versi 23.0. Uji

${ }^{18}$ Agus Irianto, Statistik: Konsep Dasar \& Aplikasinya, (Jakarta: Kencana Prenata Media Group, 2007), h. 274-275 
kehomogenan menghasilkan banyak keluaran. Untuk keperluan penelitian umumnya, hanya perlu keluaran Test of Homogenity of Variance saja, Pengambilan keputusan dari hasil uji homogenitas varian sebagai berikut:

1) Jika nilai signifikansi $>0,05$ dapat disimpulkan bahwa varian sama secara signifikan (homogen)

2) Jika nilai signifikansi $<0,05$ dapat disimpulkan bahwa varian berbeda secara signifikan (tidak homogen)

\section{Linearitas}

Uji linearitas bertujuan untuk mengetahui apakah dua variable mempunyai hubungan yang linear atau tidak secara signifikan. Uji kelinearan dilakukan untuk menguji hipotesis. Uji linieritas dilakukan dilakukan dengan mencari persamaan garis regresi variabel bebas X terhadap variabel terikat Y. Perhitungan dengan menggunakan SPSS Versi 23.0 .

\section{PEMBAHASAN}

Deskripsi statistik dari hasil perhitungan dan pengujian yang dilakukan dengan bantuan komputer melalui program aplikasi komputer SPSS 23.0, serta analisis dan pembahasannya. Diawali dengan perhitungan uji coba angket dengan memperlihatkan validitas dan reliabilitas angket, karena hanya angket yang valid dan reliabel yang dapat digunakan sebagai alat untuk penelitian.

\section{Validitas Angket Perhatian Orang Tua}

Uji validitas terhadap angket variabel perhatian orang tua dikatakan valid apabila mampu mengukur apa yang diinginkan dan dapat mengungkap data dari variabel yang diteliti secara tetap. Uji validitas angket dilakukan dnegan bantuan komputer program SPSS versi 23.0 for windows dengan rumus korelasi product moment. Validitas angket dilaksanakan sebelum penelitian kepada kelas IV MI Al Makmur Kelas B, sebanyak 33 siswa. Sehingga $n=33$ pada $\alpha=0,05$ maka diperoleh $r$ tabel sebesar $0,334^{19}$ sehingga apabila nilai $r$ hitung diperoleh lebih besar dari $r$ tabel maka butir soal dinyatakan valid, berikut adalah hasil uji validitas angket yang dilakukan perhitungan dengan SPSS Versi 23.0:

Tabel 4.1.

Hasil Uji Validitas Angket Perhatian Orang Tua

${ }^{19}$ Tabel harga kritik dari r Product Moment, pada $n=33$ dan interval kepercayaan 95\% dalam Suharsimi Arikunto, Prosedur Penelitian, (Jakarta: Rinekacipta, 2013), h. 402 


\begin{tabular}{|l|l|l|l|}
\hline $\begin{array}{l}\text { Butir } \\
\text { Pernyataan }\end{array}$ & $\begin{array}{l}\text { r } \\
\text { hitung }\end{array}$ & r tabel & Keterangan \\
\hline Soal1 & 0,868 & 0,344 & Valid \\
\hline Soal2 & 0,859 & 0,344 & Valid \\
\hline Soal3 & 0,867 & 0,344 & Valid \\
\hline Soal4 & 0,863 & 0,344 & Valid \\
\hline Soal5 & 0,866 & 0,344 & Valid \\
\hline Soal6 & 0,878 & 0,344 & Valid \\
\hline Soal7 & 0,873 & 0,344 & Valid \\
\hline Soal8 & 0,883 & 0,344 & Valid \\
\hline Soal9 & 0,874 & 0,344 & Valid \\
\hline Soal10 & 0,894 & 0,344 & Valid \\
\hline
\end{tabular}

Berdasarkan pada tabel di atas diperoleh sebanyak 24 butir pernyataan yang digunakan sebagai angket penelitian angket perhatian orang tua valid dan layak digunakan penelitian karena keseluruhan butir soal diperoleh $r$ hitung lebih besar dari $r$ tabel.

\section{Reliabilitas Angket Perhatian Orang Tua}

Reliabilitas angket dilakukan dengan menggunakan SPSS Versi 23.0 yang kemudian akan dilakukan perbandingan dengan tabel interpretasi koefisien yang sudah diajukan pada bab III. Diperoleh hasil sebagai berikut:

Tabel 4.2.

Hasil Uji Reliabilitas Angket Perhatian Orang Tua

Reliability Statistics

\begin{tabular}{|l|l|}
\hline $\begin{array}{l}\text { Cronbach's } \\
\text { Alpha }\end{array}$ & N of Items \\
\hline 884 & 10 \\
\hline
\end{tabular}

Hasil Reliabilitas angket perhatiang orang tua diperoleh hasil sebesar 0,884 yang berarti angket memiliki reliabilitas yang sangat tinggi karena sesuai dengan tabel 3.4 . tentang klasifikasi koefisien reliabilitas angka 0,884 berada pada interval 0,80-1,00 yang berarti angket perhatian orang tua sangat reliabel.

\section{Validitas dan Reliabilitas Ketercapaian Kecerdasan Kognisi}

Validitas ketercapaian kecerdasan kognisi anak yang berupa hasil belajar yang dilakukan dengan memberikan tes dengan 26 butir soal dilaksanakan sebelum penelitian 
kepada kelas IV MI Al Makmur Kelas B, sebanyak 33 siswa. Sehingga $n=33$ pada $\alpha=0,05$ maka diperoleh $r$ tabel sebesar $0,334^{20}$ sehingga apabila nilai $r$ hitung diperoleh lebih besar dari $r$ tabel maka butir soal dinyatakan valid, berikut adalah hasil uji validitas angket yang dilakukan perhitungan dengan SPSS Versi 23.0:

Tabel 4.3.

Hasil Uji Validitas Ketercapaian Kecerdasan Kognisi

\begin{tabular}{|l|l|l|l|}
\hline $\begin{array}{l}\text { Butir } \\
\text { Pernyatan }\end{array}$ & $\begin{array}{l}\text { hitung } \\
\text { r tabel }\end{array}$ & Keterangan \\
\hline Soal1 & 0,696 & 0,344 & Valid \\
\hline Soal2 & 0,701 & 0,344 & Valid \\
\hline Soal3 & 0,675 & 0,344 & Valid \\
\hline Soal4 & 0,696 & 0,344 & Valid \\
\hline Soal5 & 0,681 & 0,344 & Valid \\
\hline Soal6 & 0,696 & 0,344 & Valid \\
\hline Soal7 & 0,686 & 0,344 & Valid \\
\hline Soal8 & 0,683 & 0,344 & Valid \\
\hline Soal9 & 0,694 & 0,344 & Valid \\
\hline Soal10 & 0,696 & 0,344 & Valid \\
\hline Soal11 & 0,707 & 0,344 & Valid \\
\hline Soal12 & 0,696 & 0,344 & Valid \\
\hline Soal13 & 0,694 & 0,344 & Valid \\
\hline Soal14 & 0,681 & 0,344 & Valid \\
\hline Soal15 & 0,687 & 0,344 & Valid \\
\hline Soal16 & 0,685 & 0,344 & Valid \\
\hline Soal17 & 0,69 & 0,344 & Valid \\
\hline Soal18 & 0,673 & 0,344 & Valid \\
\hline Soal19 & 0,691 & 0,344 & Valid \\
\hline Soal20 & 0,686 & 0,344 & Valid \\
\hline Soal21 & 0,683 & 0,344 & Valid \\
\hline Soal22 & 0,684 & 0,344 & Valid \\
\hline Soal23 & 0,684 & 0,344 & Valid \\
\hline Soal24 & 0,698 & 0,344 & Valid \\
\hline Soal25 & 0,681 & 0,344 & Valid \\
\hline Soal26 & 0,712 & 0,344 & Valid \\
\hline
\end{tabular}

${ }^{20}$ Tabel harga kritik dari $\mathrm{r}$ Product Moment, pada $\mathrm{n}=33$ dan interval kepercayaan $95 \%$ dalam Suharsimi Arikunto, Prosedur Penelitian, (Jakarta: Rinekacipta, 2013), h. 402 
Berdasarkan pada tabel di atas diperoleh sebanyak 24 butir pernyataan yang digunakan sebagai angket penelitian angket perhatian orang tua valid dan layak digunakan penelitian karena keseluruhan butir soal diperoleh $r$ hitung lebih besar dari $r$ tabel.

\section{Reliabilitas Angket}

Reliabilitas angket dilakukan dengan menggunakan SPSS Versi 23.0 yang kemudian akan dilakukan perbandingan dengan tabel interpretasi koefisien yang sudah diajukan pada bab III. Diperoleh hasil sebagai berikut:

Tabel 4.4.

Hasil Uji Reliabilitas Ketercapaian Kecerdasan Kognisi

Reliability Statistics

\begin{tabular}{|l|l|}
\hline $\begin{array}{l}\text { Cronbach's } \\
\text { Alpha }\end{array}$ & N of Items \\
\hline, 698 & 26 \\
\hline
\end{tabular}

Hasil Reliabilitas angket perhatiang orang tua diperoleh hasil sebesar 0,698 yang berarti angket memiliki reliabilitas yang sangat tinggi karena sesuai dengan tabel 3.4. tentang klasifikasi koefisien reliabilitas angka 0,698 berada pada interval 0,60-0,799, yang berarti angket hasil belajar reliabel.

\section{Analisis Data Variabel Perhatian Orang Tua (X)}

Data perhatian orang tua diperoleh dari sebaran angket kemudian dilakukan koding dari setiap butir jawaban terhadap pernyataan. Skor perhatian orang tua yang diperoleh dari responden mempunyai rata-rata 39,88 dengan simpangan baku 5,266 median sebesar 40, skor minimum 27 dan skor maksimum 49.

\section{Tabel 4.5.}

Deskripsi statistik Skor Perhatian Orang Tua (X)

Statistics

Perhatian Orang Tua (X)

\begin{tabular}{|c|c|}
\hline $\begin{array}{l}\text { Valid } \\
\quad \text { Missing } \\
\text { Mean } \\
\text { Median } \\
\text { Mode } \\
\text { Std. Deviation } \\
\text { Variance } \\
\text { Range } \\
\text { Minimum } \\
\text { Maximum }\end{array}$ & \begin{tabular}{|l}
33 \\
0 \\
39,88 \\
40,00 \\
40 \\
5,266 \\
27,735 \\
22 \\
27 \\
49
\end{tabular} \\
\hline
\end{tabular}




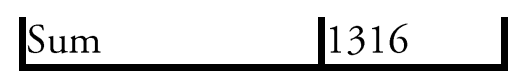

Skor rata-rata tiap pertanyaan adalah 39,88 pada perhatian orang tua dapat diartikan adalah sebagian besar jawaban adalah berada pada angka antara 30 (skor maksimal jawaban Kadang-kadang) dan 40 (skor maksimal untuk jawaban Sering) yang dapat diartikan bahwa perhatian orang tua siswa kelas IV MI Al Makmur memiliki rata-rata yang cukup baik.

Tabel 4.6.

Distribusi Frekuensi Skor Perhatian Orang Tua (X)

Perhatian Orang Tua (X)

\begin{tabular}{|c|c|c|c|c|c|}
\hline & & Frequency & Percent & Valid Percent & $\begin{array}{l}\text { Cumulative } \\
\text { Percent }\end{array}$ \\
\hline \multirow{20}{*}{$\overline{\text { Valid }}$} & 27 & 1 & 3,0 & 3,0 & 3,0 \\
\hline & 30 & 1 & 3,0 & 3,0 & 6,1 \\
\hline & 33 & 1 & 3,0 & 3,0 & 9,1 \\
\hline & 34 & 1 & 3,0 & 3,0 & 12,1 \\
\hline & 35 & 1 & 3,0 & 3,0 & 15,2 \\
\hline & 36 & 3 & 9,1 & 9,1 & 24,2 \\
\hline & 37 & 3 & 9,1 & 9,1 & 33,3 \\
\hline & 38 & 2 & 6,1 & 6,1 & 39,4 \\
\hline & 39 & 3 & 9,1 & 9,1 & 48,5 \\
\hline & 40 & 5 & 15,2 & 15,2 & 63,6 \\
\hline & 41 & 1 & 3,0 & 3,0 & 66,7 \\
\hline & 42 & 1 & 3,0 & 3,0 & 69,7 \\
\hline & 43 & 1 & 3,0 & 3,0 & 72,7 \\
\hline & 44 & 1 & 3,0 & 3,0 & 75,8 \\
\hline & 45 & 2 & 6,1 & 6,1 & 81,8 \\
\hline & 46 & 1 & 3,0 & 3,0 & 84,8 \\
\hline & 47 & 2 & 6,1 & 6,1 & 90,9 \\
\hline & 48 & 2 & 6,1 & 6,1 & 97,0 \\
\hline & 49 & 1 & 3,0 & 3,0 & 100,0 \\
\hline & Total & 33 & 100,0 & 100,0 & \\
\hline
\end{tabular}

Berdasarkan tabel distribusi frekuensi di atas dapat dilihat skor di atas 72 diperoleh sebesar $82 \%$ hal ini menunjukkan perhatian orang tua yang baik pada siswa kelas IV pada prosentase yang besar. 


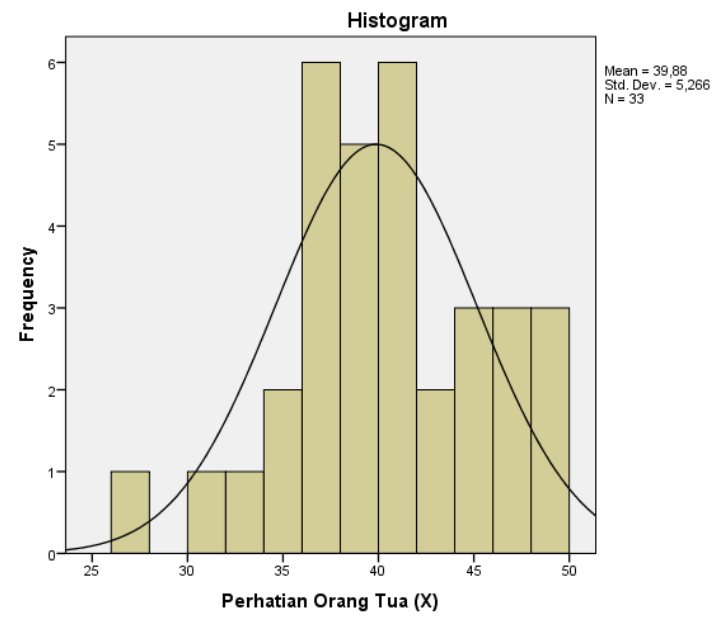

Gambar 4.1. Histogram Data Skor Perhatian Orang Tua

Dari tabel distribusi, histogram dan poligon frekwensi dapat disimpulkan bahwa data skor skala perhatian orang tua dalam penelitian ini memiliki sebaran yang cenderung normal.

\section{Analisis Data Ketercapaian Kecerdasan Kognisi IPS (Y)}

Data untuk ketercapaian kecerdasan kognisi anak berupa hasil belajar diperoleh dari nilai yang ada pada guru kelas untuk nilai ulangan IPS siswa kelas IV di MI Al Makmur yang sudah dilaksanakan pada pekan ulangan bulan Oktober 2016 semester ganjil tahun pelajaran 2016/2017. Data hasil belajar IPS yang diperoleh responden mempunyai rata-rata 81,09 dengan simpangan baku 11,05, median sebesar 80, skor minimum 56 dan skor maksimum 100. Hal ini menunjukkan bahwa rata-rata hasil belajar IPS yang dimiliki responden termasuk sedang. Jika mempertimbangkan ketuntasan belajar dimana siswa dikatakan tuntas belajar jika nilai yang diperoleh di atas Kriteria Ketuntasan Minimal (KKM) yang ditetapkan oleh sekolah.

KKM mata pelajaran IPS kelas IV di sekolah tempat penelitian adalah 75, maka banyaknya responden yang tuntas belajar sebanyak $76 \%$. Jadi jika dilihat dari ketuntasan belajar, maka prestasi belajar IPS yang dimiliki responden sedang. Hasil ini sesuai dengan nilai ulangan pelajaran IPS yang ada pada guru kelas IV.

Tabel 4.7.

Deskripsi statistik Skor Ketercapaian Kecerdasan Kognisi (Y)

Statistics

Ketercapaian Kecerdasan

Kognisi IPS (Y)

\begin{tabular}{|ll|l|}
\hline N & Valid & 33 \\
& Missing & 1 \\
Mean & & 81,0909
\end{tabular}




\begin{tabular}{|l|l|} 
Median & 80,0000 \\
Mode & 88,00 \\
Std. Deviation & 11,05770 \\
Variance & 122,273 \\
Range & 44,00 \\
Minimum & 56,00 \\
Maximum & 100,00 \\
Sum & 2676,00 \\
\hline
\end{tabular}

Berdasarkan hasil deskripsi statistik nilai yang banyak muncul adalah sebesar 88 hal ini menunjukkan skor di di atas nilai KKM (75) yang besar. Nilai rata-rata pada angka skor 81 merupakan nilai di atas nilai KKM yang ditetapkan oleh guru kelas menunjukkan nilai hasil belajar IPS kelas IV MI Al Makmur tergolong tinggi.

Tabel 4.8.

Distribusi Frekuensi Ketercapaian Kecerdasan Kognisi (Y)

Ketercapaian Kecerdasan Kognisi IPS (Y)

\begin{tabular}{|c|c|c|c|c|c|}
\hline & & Frequency & Percent & Valid Percent & $\begin{array}{l}\text { Cumulative } \\
\text { Percent }\end{array}$ \\
\hline \multirow[t]{13}{*}{ Valid } & 56,00 & 1 & 2,9 & 3,0 & 3,0 \\
\hline & 60,00 & 1 & 2,9 & 3,0 & 6,1 \\
\hline & 64,00 & 1 & 2,9 & 3,0 & 9,1 \\
\hline & 68,00 & 2 & 5,9 & 6,1 & 15,2 \\
\hline & 72,00 & 3 & 8,8 & 9,1 & 24,2 \\
\hline & 76,00 & 5 & 14,7 & 15,2 & 39,4 \\
\hline & 80,00 & 4 & 11,8 & 12,1 & 51,5 \\
\hline & 84,00 & 4 & 11,8 & 12,1 & 63,6 \\
\hline & 88,00 & 6 & 17,6 & 18,2 & 81,8 \\
\hline & 92,00 & 1 & 2,9 & 3,0 & 84,8 \\
\hline & 96,00 & 3 & 8,8 & 9,1 & 93,9 \\
\hline & 100,00 & 2 & 5,9 & 6,1 & 100,0 \\
\hline & Total & 33 & 97,1 & 100,0 & \\
\hline Missing & System & 1 & 2,9 & & \\
\hline Total & & 34 & 100,0 & & \\
\hline
\end{tabular}

Berdasarkan distribusi frekuensi di atas diperoleh nilai di bawah KKM (75) sebanyak 24,2\% dari total keseluruhan kelas sehingga nilai di atas KKM diperoleh sebesar 75,8\% yang menunjukkan angka prosentase ketuntasan belajar IPS yang cukup tinggi karena telah lebih dari 50\% kelas tuntas belajar IPS dalam materi Peta Indonesia. Deskripsi data persebaran dapat dilihat dalam histogram berikut ini. 


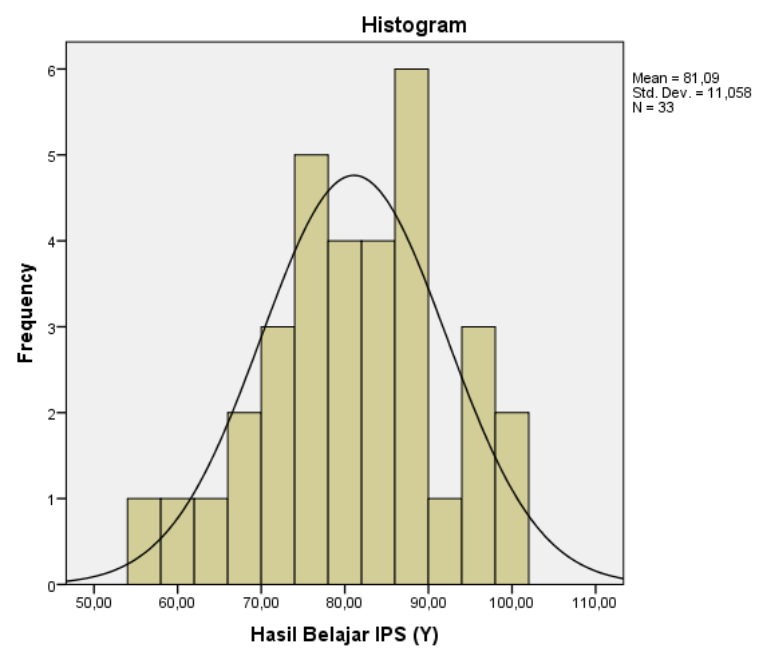

Gambar 4.2. Histogram Data Skor Prestasi Belajar IPS (Y)

Dari data distribusi, histogram dan poligon frekwensi dapat disimpulkan bahwa data skor skala prestasi belajar IPS dalam penelitian ini memiliki sebaran yang cenderung normal. Dengan grafik batang yang tertinggi pada angka 90 yang menunjukkan nilai yang tinggi pada hasil belajar IPS siswa kelas IV di MI Al Makmur .

Analisis Keterkaitan Perhatian Orang Tua (X) dengan Ketercapaian Kecerdasan Kognisi IPS (Y) Siswa Kelas IV

Keterkaitan Perhatian Orang Tua (X) dengan Kecerdasan Kognisi IPS (Y) Siswa Kelas IV diperoleh hasil sebagai berikut :

Tabel 4.9.

Hasil Analisis Keterkaitan

\begin{tabular}{|c|c|c|c|c|c|c|c|}
\hline \multirow{2}{*}{ No } & \multirow{2}{*}{$\begin{array}{l}\text { Skor } \\
\text { Perhatian } \\
\text { Orang } \\
\text { Tua }\end{array}$} & \multirow{2}{*}{$\begin{array}{l}\text { Nilai } \\
\text { Ketercapaian } \\
\text { Kecerdasan } \\
\text { Kognisi }\end{array}$} & \multicolumn{5}{|c|}{ Keterangan } \\
\hline & & & $\begin{array}{l}\text { Sangat } \\
\text { Rendah }\end{array}$ & Rendah & Cukup & Baik & $\begin{array}{l}\text { Sangat } \\
\text { Baik }\end{array}$ \\
\hline 1 & 40 & 88 & & & & & $\bullet$ \\
\hline 2 & 38 & 80 & & & & $\bullet$ & \\
\hline 3 & 41 & 80 & & & & $\bullet$ & \\
\hline 4 & 43 & 92 & & & & & $\bullet$ \\
\hline 5 & 37 & 72 & & & & $\bullet$ & \\
\hline 6 & 35 & 64 & & & $\bullet$ & & \\
\hline 7 & 40 & 88 & & & & & $\bullet$ \\
\hline 8 & 38 & 76 & & & & $\bullet$ & \\
\hline 9 & 44 & 88 & & & & & $\bullet$ \\
\hline 10 & 42 & 80 & & & & $\bullet$ & \\
\hline
\end{tabular}




\begin{tabular}{|c|c|c|c|c|c|c|c|}
\hline \multirow{2}{*}{ No } & \multirow{2}{*}{$\begin{array}{l}\text { Skor } \\
\text { Perhatian } \\
\text { Orang } \\
\text { Tua }\end{array}$} & \multirow{2}{*}{$\begin{array}{l}\text { Nilai } \\
\text { Ketercapaian } \\
\text { Kecerdasan } \\
\text { Kognisi }\end{array}$} & \multicolumn{5}{|c|}{ Keterangan } \\
\hline & & & $\begin{array}{l}\text { Sangat } \\
\text { Rendah }\end{array}$ & Rendah & Cukup & Baik & $\begin{array}{l}\text { Sangat } \\
\text { Baik }\end{array}$ \\
\hline 11 & 47 & 88 & & & & & • \\
\hline 12 & 37 & 76 & & & & • & \\
\hline 13 & 39 & 80 & & & & • & \\
\hline 14 & 37 & 72 & & & & • & \\
\hline 15 & 40 & 84 & & & & $\cdot$ & \\
\hline 16 & 33 & 60 & & & • & & \\
\hline 17 & 46 & 88 & & & & & • \\
\hline 18 & 36 & 72 & & & & $\bullet$ & \\
\hline 19 & 30 & 68 & & & $\cdot$ & & \\
\hline 20 & 48 & 96 & & & & & • \\
\hline 21 & 40 & 84 & & & & & $\bullet$ \\
\hline 22 & 27 & 56 & & $\bullet$ & & & \\
\hline 23 & 49 & 100 & & & & & $\bullet$ \\
\hline 24 & 48 & 100 & & & & & $\cdot$ \\
\hline 25 & 39 & 76 & & & & $\cdot$ & \\
\hline 26 & 40 & 84 & & & & & • \\
\hline 27 & 45 & 96 & & & & & $\cdot$ \\
\hline 28 & 39 & 88 & & & & $\bullet$ & \\
\hline 29 & 36 & 76 & & & & • & \\
\hline 30 & 45 & 96 & & & & & $\bullet$ \\
\hline 31 & 36 & 68 & & & $\bullet$ & & \\
\hline 32 & 47 & 84 & & & & $\bullet$ & \\
\hline 33 & 34 & 76 & & & & $\bullet$ & \\
\hline
\end{tabular}

Sangat Rendah : $1-24$

Rendah : :25-48

Cukup : :49-72

Baik : $73-96$

Sangat Baik $\quad: 97-120^{21}$

Hasil tabel di atas menunjukkan siswa dengan perhatian orang tua yang rendah sebanyak 1 siswa dengan hasil belajar IPS di bawah KKM yaitu sebesar 56, siswa dengan perhatian orang tua yang cukup sebanyak 4 siswa dengan hasil belajar di bawah KKM, sedangkan siswa dengan perhatian orang tua yang baik memperoleh hasil belajar di atas

\footnotetext{
${ }^{21}$ Suharsimi Arikunto, op.cit, h. 35, Berdasarkan skala likert dengan skoring jumlah skor terendah $=$ skoring terendah $\mathrm{x}$ jumlah pertanyaan, Jumlah skor tertinggi $=$ skoring tertinggi $\mathrm{x}$ jumlah pertanyaan.
} 
KKM sebanyak 15 siswa, dan siswa yang memiliki perhatian orang tua sangat baik sebanyak 13 siswa memperoleh hasil belajar di atas KKM. Hal ini menunjukkan bahwa siswa yang mendapatkan perhatian orang tua dengan baik dapat mencapai kecerdasan kognisi yang baik dengan hasil belajar yang baik juga.

\section{Uji Homogenitas}

Uji homogenitas digunakan untuk mengetahui apakah kedua kelompok sampel berasal dari populasi yang sama atau tidak sama dengan menggunakan SPSS diperolah hasil sebagai berikut.

Tabel 4.11.

Hasil Uji Homogenitas Data

Test of Homogeneity of Variances Perhatian Orang Tua (X)

\begin{tabular}{|c|c|c|}
\hline Levene Statisticdf1 & $\mathrm{df} 2$ & Sig. \\
\hline 1,899 & 14 & 1,145 \\
\hline
\end{tabular}

Berdasarkan hasil uji homogenitas di atas diperoleh nilai sig. Sebesar 0,145 yang lebih besar dari nilai sig.0,05 hal ini menunjukkan data homogen dan dapat untuk dilanjutkan kepada penelitian selanjutnya.

\section{Pengujian Linearitas Garis Regresi}

Pengujian linearitas dalam penelitian ini digunakan hipotesis sebagai berikut :

$\mathrm{H}_{0}$ : garis regresi Pengaruh variabel $\mathrm{X}$ dan variabel $\mathrm{Y}$ linear

$\mathrm{H}_{1}$ : garis regresi Pengaruh variabel $\mathrm{X}$ dan variabel $\mathrm{Y}$ tidak linear

Perhitungan dilakukan dengan bantuan komputer melalui program aplikasi SPSS 23.0. Menurut ketentuan yang ada pada program tersebut maka kriteria dari normalitas data adalah "jika $\operatorname{Sig}>0.05$ maka $\mathrm{H}_{0}$ diterima", yang berarti bahwa garis regresi tersebut linear. Nilai Sig adalah bilangan yang tertera pada kolom Sig baris Deviation from Linearity dalam table ANOVA hasil perhitungan pengujian linearitas garis regresi oleh program SPSS.

Tabel 4.12.

Rekapitulasi Hasil Pengujian Linearitas Garis Regresi Pengaruh Variabel X terhadap Variabel Y

ANOVA Table 


\begin{tabular}{|c|c|c|c|}
\hline & & & Sig. \\
\hline \multirow{3}{*}{$\begin{array}{l}\text { Hasil Belajar IPSBetween Groups } \\
\text { (Y) * Perhatian } \\
\text { Orang Tua }(\mathrm{X})\end{array}$} & (Combined) & & 000 \\
\hline & Linearity & &, 000 \\
\hline & Deviation & from & ,017 \\
\hline Within Groups & & & \\
\hline Total & & & \\
\hline
\end{tabular}

Dari tabel di atas terlihat bahwa nilai pada kolom Sig baris Deviation from Linearity adalah 0,017 lebih kecil dari 0,05 , sehingga $\mathrm{H}_{0}$ diterima, dengan kata lain bahwa garis regresi antara variabel $\mathrm{X}_{1}$ dan variabel $\mathrm{Y}$ tersebut adalah linear.

\section{Uji Hipotesis}

Pengujian hipotesis akan dilakukan secara berturut-turut, dimulai dari perhitungan regresi linier Peranan Perhatian Orang Tua (X) dalam menstimulus Kecerdasan Kognisi anak $(\mathrm{Y})$. Persamaan regresi linier terhadap variabel $\mathrm{x}$ dan variabel $\mathrm{y}$, kemudian yang terakhir Pengujian keberartian koefisiein korelasi sederhana pada hipotesis menggunakan ujit t. Dan menentukan besar kontribusi yang diberikan perhatian orang tua terhadap hasil belajar IPS siswa kelas IV.

Hipotesis menyatakan $\left(\mathrm{H}_{1}\right)$ terdapat pengaruh antara Peranan Perhatian Orang Tua (X) Dalam Menstimulus Kecerdasan Kognisi Anak (Y). Secara statistik hipotesis tersebut dinyatakan dengan: $\mathrm{H}_{0}: \mathrm{r}=0$ (tidak terdapat Pengaruh Peranan Perhatian Orang Tua dalam menstimulus Kecerdasan Kognisi Anak) lawan $\mathrm{H}_{1}: \mathrm{r}>0$ (terdapat pengaruh positif antara Peranan Perhatian Orang Tua dalam Menstimulus Kecerdasan Kognisi Anak).

Koefisien korelasi rhitung dihitung dengan menggunakan teknik analisis regresi dan korelasi sederhana sedangkan pengujian keberartiannya menggunakan uji t. Hasil perhitungan dengan SPSS disajikan pada tabel berikut:

Tabel 4.13.

Analisis Regresi Perhatian Orang Tua (X) terhadap Motivasi Ketercapaian Kecerdasan Kognisi Anak (Y)

\begin{tabular}{|c|c|c|c|c|c|c|}
\hline \multirow[b]{3}{*}{ Model } & & & del $S_{l}$ & ary ${ }^{b}$ & & \\
\hline & \multirow[b]{2}{*}{$\mathrm{R}$} & \multirow[b]{2}{*}{$\begin{array}{l}\mathrm{R} \\
\text { Square }\end{array}$} & \multirow[b]{2}{*}{$\begin{array}{l}\text { Adjusted } \\
\mathrm{R} \\
\text { Square }\end{array}$} & \multirow{2}{*}{$\begin{array}{l}\text { Std. } \\
\text { Error of } \\
\text { the } \\
\text { Estimate }\end{array}$} & \multicolumn{2}{|c|}{ Change Statistics } \\
\hline & & & & & $\begin{array}{l}\mathrm{R} \\
\text { Square } \\
\text { Change }\end{array}$ & $\begin{array}{l}\mathrm{F} \\
\text { Change }\end{array}$ \\
\hline 1 &, $895^{a}$ & 0,802 & 0,795 & 5,005 & 0,802 & 125,204 \\
\hline
\end{tabular}


Perhitungan dengan SPSS menghasilkan nilai rhitung sebesar $=0,895$. Berdasarkan tabel interpretasi korelasi angka 0,895 berada pada interval 0,800-0,899 yang berarti peranan perhatian orang tua dapat menstimulus Ketercapaian Kecerdasan Kognisi anak. Pengujian hipotesis menggunakan tabel uji t untuk mengetahui hipotesis yang diajukan diterima atau ditolak. Hasil perhitungan SPSS diperoleh hasil sebagai berikut:

Tabel 4.14 .

Uji Signifikansi Koefisien Korelasi Perhatian Orang Tua (X) terhadap Motivasi

Ketercapaian Kecerdasan Kognisi Anak (Y)

Coefficients $^{\mathrm{a}}$

\begin{tabular}{|l|l|l|l|l|}
\hline \multirow{2}{*}{ Model } & \multicolumn{2}{|l|}{$\begin{array}{l}\text { Unstandardized } \\
\text { Coefficients }\end{array}$} & $\begin{array}{l}\text { Standardized } \\
\text { Coefficients }\end{array}$ & \multirow{2}{*}{$\mathrm{t}$} \\
\cline { 2 - 4 } & $\mathrm{B}$ & $\begin{array}{l}\text { Std. } \\
\text { Error }\end{array}$ & Beta & 0,907 \\
\hline $\begin{array}{l}\text { (Constant) } \\
\begin{array}{l}\text { Perhatian } \\
\text { Orang Tua } \\
(\mathrm{X})\end{array}\end{array}$ & 6,126 & 6,756 & & 11,189 \\
\hline
\end{tabular}

Berdasarkan tabel di atas dapat dibuat persamaan regresi linier peranan perhatian orang tua dalam menstimulus kecerdasan kognisi anak sebagai berikut :

$\mathrm{Y}=6,126+0,895 \mathrm{X}$

Yang berarti bahwa apabila skor X bertambah 1 poin maka skor $Y$ akan bertambah sebesar 0,895 pada nilai konstan sebesar 6,126. Hal ini menunjukkan adanya pengaruh positif peranan perhatian orang tua dalam menstimulus kecerdasan kognisi anak.

Sedangkan pengujian keberartian koefisien korelasi menghasilkan t hitung yang lebih besar dari $t_{\text {tabel }}$ dengan $\mathrm{dk}=\mathrm{n}-\mathrm{k}=33-2=31$ pada taraf signifikansi 0,05 uji satu sisi adalah 1.695 yang berarti $t_{\text {hitung }}(11,189)$ lebih besar dari $t_{\text {tabel }}(1,695)$ hal ini berarti $H_{o}$ ditolak. Dengan demikian hipotesis penelitian terbukti kebenarannya bahwa peranan perhatian orang tua berpengaruh positif dalam menstimulus kecerdasan kognisi anak. Dengan mengkuadratkan koefisien korelasi $r=0,895$ diperoleh koefisien determinasi $r^{2}=0,802$, yang menunjukkan bahwa variasi peranan perhatian orang tua dapat dijelaskan oleh variasi kecerdasan kognisi anak sebesar 80\%.

Dengan demikian dalam penelitian ini Peranan Perhatian Orang Tua variabel utama dan memberikan kontribusi terbesar, artinya siswa yang memiliki Perhatian Orang Tua yang baik, maka ada kecenderungan menstimulus kecerdasan kognisi yang tinggi pula. 
Validitas angket pada penelitian ini dikatakan valid karena nilai pada masing-masing butir pernyataan rhitung diperoleh lebih besar dari pada rtabel. Hal ini juga sesuai dengan teori Suharsimi Arikunto, bahwa angket dikatakan valid apabila $\mathrm{r}$ hitung $>\mathrm{r}_{\text {tabel. }}{ }^{22}$

Reliabilitas angket pada penelitian ini diperoleh hasil sebesar 0,829 yang berarti angket memiliki reliabilitas yang sangat tinggi karena sesuai dengan tabel 3.4. tentang klasifikasi koefisien reliabilitas angka 0,829 berada pada interval 0,80-1,00 yang berarti angket perhatian orang tua sangat reliabel. Hal ini sesuai dengan teori yang disampaikan oleh Suharsimi Arikunto bahwa apabila diperoleh rhitung berada pada interval 0,80-1,00 maka angket dinyatakan memiliki reliabilitas yang sangat tinggi. ${ }^{23}$

Penelitian ini menunjukkan pentingnya peranan perhatian orang tua dalam menstimulus kecerdasan kognisi anak yang sesuai dengan pendapat Suryabrata yang menyampaikan bahwa, "Perhatian orang tua dengan penuh kasih sayang terhadap pendidikan anaknya, akan menumbuhkan aktivitas anak sebagai suatu potensi yang sangat berharga untuk menghadapi masa depan." ${ }^{24}$ Orang tua memiliki inisiatif untuk mengamati dan menanyakan kegiatan belajar anak, membantu anak dalam kesulitannya memahami pelajaran terutama pada pembelajaran IPS.

Dimyati menyampaikan bahwa, "hasil belajar adalah hasil yang dicapai dalam bentuk angka-angka atau skor setelah diberikan tes hasil belajar pada setiap akhir pembelajaran." ${ }^{25}$ Hal ini ditunjukkan dengan hasil penelitian dan perhitungan secara stastistik dengan menggunakan uji-t pada $\alpha=0,05$ diperoleh harga $t_{\text {hitung }}$ sebesar 11,189 lebih besar daripada $\mathrm{t}_{\text {tabel }}$ 1,695. Sehingga hipotesis nol ditolak dan $\mathrm{H}_{1}$ diterima, itu artinya terdapat pengaruh peranan pehatian orang tua dalam menstimulus kecerdasan kognisi anak yang tampak pada hasil belajar IPS siswa kelas IV MI Al Makmur Ciganjur Jakarta Selatan. Sesuai dengan Purwanto bahwa, "hasil belajar adalah pencapaian tujuan pendidikan pada peserta didik yang mengikuti proses belajar mengajar." ${ }^{26}$ Hasil belajar merupakan komponen pendidikan yang harus disesuaikan dengan tujuan pendidikan, karena hasil belajar di ukur untuk mengetahui ketercapaian tujuan pendidikan melalui proses belajar mengajar.

Pengaruh tersebut dapat dilihat dari nilai rata-rata perhatian orang tua yang diperoleh oleh siswa adalah sebesar 91,24 yang menunjukkan angka perhatian yang cukup tinggi dengan rata-rata hasil belajar siswa yang di atas nilai KKM yaitu sebesar 81 menunjukkan hasil belajar yang baik pula, sehingga tujuan pembelajaran dapat dicapai dengan baik. Hal ini sesuai dengan yang disampaikan oleh Anita Lie, dkk. bahwa,

\footnotetext{
${ }^{22}$ Suharsimi Arikunto, Prosedur Penelitian, (Jakarta: Rineka Cipta, 2013), h. 203

${ }^{23}$ Suharsimi Arikunto, Prosedur Penelitian, h. 203

${ }^{24}$ Suryabrata, Psikologi Pendidikan, h. 43

${ }^{25}$ Dimyati, Mudjiono, Belajar dan Pembelajaran (Jakarta: Penerbit Rineka Cipta,2006), h. 5

${ }^{26}$ Purwanto, Evaluasi Hasil Belajar (Yogyakarta: Pustaka Pelajar, 2013), h.46
} 
"Keterlibatan orangtua dalam proses pendidikan anak terbukti membawa pengaruh yang baik dalam kehidupan akademis anak perhatian menunjukkan tingginya perhatian orang tua pada pendidikan anak berbanding sejajar dengan prestasi anak." 27 Pada anak dengan perhatian orang tua yang baik akan mampu menstimulai tingkat kecerdasan kognisi sehingga anak dapat melaksanakan pembelajaran di rumah, tidak hanya di sekolah, anak akan dapat terbantu oleh bimbingan dan perhatian dari orang tua ketika menumukan kesulitan. Dengan demikian siswa aktif dalam memecahkan masalah dan dapat mengembangkan potensi yang ada pada dirinya.

Perhatian orang tua juga sangat diperlukan bagi anak kelas IV MI untuk meningkatkan hasil belajarnya dari segi kebutuhan sosialnya, orang tua yang memperhatikan pergaulan anak, mengarahkan anak untuk dapat menciptakan kerjasama dengan orang lain, juga orang tua yang memperhatikan kegiatan organisasi yang diikuti anak membuat anak merasa diperhatikan dan merasakan kehadiran orang tua mereka bagi dirinya, hal ini akan menumbuhkan dorongan pada anak untuk memberikan yang terbaik kepada orang tuanya termasuk dalam hasil belajarnya. Anak yang dilengkapi kebutuhan belajarnya akan memiliki semangat dan keinginan untuk belajar sehingga dapat meningkatkan hasil belajarnya, demikian pula sebaliknya, bagi anak yang tidak terpenuhi fasilitas belajarnya dan tidak diperhatikan kebutuhannya dalam belajar membuat anak enggan belajar dan cenderung malas dalam belajar, hal ini menyebabkan rendahnya hasil belajar siswa.

\section{KESIMPULAN}

Berdasarkan penelitian ini dapat disimpulkan bahwa Peranan Pengaruh Perhatian Orang Tua (X) dalam menstimulus Kecerdasan Kognisi Anak (Y) dengan koefisien korelasi sebesar 0,953. Artinya makin tinggi Perhatian Orang Tua cenderung semakin tinggi tingkat kecerdasan Kognisi anak yang dapat dilihat dari Hasil Belajar Siswa IPS, sebaliknya makin rendah Perhatian Orang Tua makin rendah tingkat kecerdasan kognisi anak yang dapat dilihat dari Hasil Belajar Siswa IPS. Oleh sebab itu variabel Perhatian Orang Tua merupakan variabel penting untuk diperhatikan. Perhatian Orang Tua menyumbang $90,8 \%$. Pengujian hipotesis thitung yang lebih besar dari $\mathrm{t}_{\text {tabel }}$ dengan $\mathrm{dk}=\mathrm{n}-\mathrm{k}=33-2=31$ pada taraf signifikansi 0,05 uji satu sisi adalah 1.695 yang berarti $t_{\text {hitung }}(17,447)$ lebih besar dari $t_{\text {tabel }}(1,695)$ hal ini berarti $H_{o}$ ditolak. Dengan demikian hipotesis penelitian terbukti kebenarannya bahwa Peranan Perhatian Orang Tua dapat menstimulus kecerdasan kognisi anak secara positif yang dapat dilihat dari hasil belajar siswa.

\footnotetext{
${ }^{27}$ Anita Lie,Takim Andriono,Sarah Prasasti, Menjadi Sekolah Terbaik: Praktik-praktik Strategi dalam Pendidikan, (Jakarta: Penerbit TANOTO Foundation, 2014), h. 162
} 


\section{DAFTAR PUSTAKA}

Agung, Iskandar. 2012. Panduan Penelitian Tindakan Kelas bagi Guru. (Jakarta: Bestari Buana Murni).

Agus Irianto. 2007. Statistik: Konsep Dasar \& Aplikasinya. (Jakarta: Kencana Prenata Media Group).

Agus Suprijono. 2013. Cooperative learning: teori \& aplikasi PAIKEM. (Jakarta: Pustaka Pelajar).

Amstrong, Thomas. 2011. The Best School: Mendidik Siswa Menjadi Insan Cendekia Seutuhnya. (Bandung: Kaifa).

Anderson L.W. and Krathwohl. 2010. Kerangka Landasan untuk Pembelajaran, Pengajaran, dan Asesmen. Revisi Taksonomi Pendidikan Bloom. (Yogyakarta: Pustaka Pelajar).

Anita Lie, Takim Andriono, Sarah Prasasti. 2014. Menjadi Sekolah Terbaik: Praktikpraktik Strategi dalam Pendidikan. (Jakarta: Penerbit TANOTO Foundation).

Chairinniza. 2017. Keberhasilan Anak di Tangan Orang Tua. (Jakarta: PT Elex Media Komputindo).

Dimyati, Mudjiono. 2016. Belajar dan Pembelajaran. (Jakarta: Penerbit Rineka Cipta).

Faisal Yatim. 2005. 30 Gangguan Kesehatan Pada Anak Usia Sekolah. (Jakarta: Pustaka Populer Obor).

Feisal Jusuf Amir. 1995. Reorientasi Pendidikan Islam. (Jakarta: Gema Insani Press).

Hasan, Muhammad Tholchah et. all. 2003. Metode penelitian Kualitatif: Tinjauan Teoritis dan Praktis. (Surabaya: Visipress Offset).

Hendra Surya. 2009. Menjadi Manusia Pembelajar. (Jakarta: PT Elex Media Komputindo).

Hendra Surya. 2007. Percaya Diri Itu Penting: Peran Orang Tua dalam Membangun Percaya Diri Anak. (Jakarta: PT Elex Media Komputindo).

Imam. 2013. Metode Penelitian. (Jakarta: UNINDRA PRESS).

Komisi Perlindungan Anak. 2004. Undang-undang Perlindungan Anak. (Jakarta: New Merah Putih).

Nana Syaodih Sukmadinata. 2004. Landasan Psikologi Proses Pendidikan. (Bandung: PT Remaja Rosdakarya).

Peraturan Pemerintah Republik Indonesia Nomor 19 Tahun 2005. (Jakarta: Kementerian Agama).

Purwanto. 2013. Evaluasi Hasil Belajar. (Yogyakarta: Pustaka Pelajar).

Redi Panuju. 1995. Komunikasi Bisnis. (Jakarta: PT. Gramedia Pustaka Utama). 
Saminanto. 2010. Ayo Praktik PTK (Penelitian Tindakan Kelas). (Semarang: RaSAIL Media Group).

Sardiman, A.M. 2011. Interaksi dan Motivasi Belajar Mengajar. (Jakarta : PT. Raja Grafindo Persada)

Siti Partini. 1997. Psikologi Perkembangan. (Yogyakarta: Universitas Negeri Malang).

Slameto. 2003. Belajar dan Faktor-Faktor yang Mempengaruhinya. (Jakarta: Rineka Cipta).

Soeparwoto. 2007. Psikologi Perkembangan. (Semarang: UPT UNNES PRESS).

Sri Esti Wuryani. 2012. Psikologi Pendidikan. (Jakarta: Grasindo).

Sugiyono. 2008. Metode Penelitian Pendidikan. (Bandung: Alfabeta).

Suharsimi Arikunto. 2013. Prosedur Penelitian. (Jakarta: Rineka Cipta).

Tabrani Rusyan dkk. 1994. Pendekatan dalam Proses Belajar-Mengajar. (Bandung: PT Remaja Rosdakarya).

Tim Dosen PAI STIT Muhammadiyah Berau. 2016. Bunga Rampai Penelitian dalam Pendidikan Agama Islam. (Yogyakarta: Deepublish).

Tim Pengembang Ilmu Pendidikan FIP-UP. 2007. Ilmu dan Aplikasi Pendidikan. (Bandung: PT. Iperial Bhakti Utama).

Undang-Undang Republik Indonesia nomor 20 tahun 2003. 2006. Tentang Sistem Pendidikan Nasional. (Bandung: Citra Umbara). 